\title{
The micropolitics of choice in Italy: How the law affects lesbian and bisexual women's daily life
}

\section{Beatrice Gusmano \& Tatiana Motterle}

To cite this article: Beatrice Gusmano \& Tatiana Motterle (2019) The micropolitics of choice in Italy: How the law affects lesbian and bisexual women's daily life, Journal of Lesbian Studies, 23:3, 336-356, DOI: $10.1080 / 10894160.2019 .1598719$

To link to this article: https://doi.org/10.1080/10894160.2019.1598719

\section{Published online: 25 Apr 2019.}

\section{Submit your article to this journal $₫$}

\section{Џ Article views: 67}

Q View related articles $₫$

View Crossmark data ¿ 


\title{
The micropolitics of choice in Italy: How the law affects lesbian and bisexual women's daily life
}

\author{
Beatrice Gusmano (D) and Tatiana Motterle (DD \\ CES-Centro de Estudos Sociais, University of Coimbra, Coimbra, Portugal
}

\begin{abstract}
This article stems from three years of fieldwork (2015-2017) in the context of a five-year-long, European-Research-Councilfunded research project called INTIMATE-Citizenship, Care and Choice: The Micropolitics of Intimacy in Southern Europe, a comparative qualitative study that involves three countries (Italy, Portugal, and Spain) and studies intimate citizenship and the micropolitics of daily life of LGBTQ people. The article focuses specifically on the Italian case and shows how non-heterosexual women deal with the scarce legislative protection Italy grants. Our aim is to reflect upon the reciprocal influence of different axes from public and private spaces and on how they impact the micropolitics and the daily choices of our lesbian, bisexual, and pansexual participants. More specifically, considering the lack of legal and social recognition of lesbian experiences in Italy, we will focus on the different strategies of reaction, assimilation, and resistance employed by participants in their private and public life. The three-year-long fieldwork covered the period between the proposal of the bill on same-sex civil unions and the first year after Act 76/2016 came into force. This allows us to sketch a brief diachronic analysis of its functioning, in particular from the perspective of the very subjects it impacts.
\end{abstract}

\section{KEYWORDS}

Intimate citizenship; lesbian invisibilization; partnership; parenting; friendship; Italian law

\section{Introduction}

Italy is a rather remarkable case in comparison to other Southern European countries in terms of LGBT rights, since these are barely recognized by law, especially regarding lesbian intimate life. We want to analyze how (the lack of) law conditions the daily life of lesbian, bisexual, and pansexual women, and what kind of strategies they use to react. We use the concept of intimate citizenship as a theoretical framework in order to underscore that the public and private dimensions are not separated at all (Cooper, 2004; Plummer, 2003). On the one hand, this means that intimate choices and practices have consequences on the socio-political dimension: they are social actions embodied in daily practices "that transform the public 
discourse" (Reynolds, 2010, p. 35). On the other hand, public norms have a strong influence on intimate lives. Subjective and intimate "private" choices and practices (such as gender and sexuality) are always public, since they are regulated by state laws and are an important subject of discussion in the public, cultural, socio-political, and media arena. Indeed, intimate practices are influenced by different levels of intersecting inequalities and, moreover, by Western liberal inclusion policies. These inequalities and policies imply the assimilation of LGBT subjects (Phelan, 2001), since institutions themselves are sexualized (Cooper, 1995) and, we would add, heterosexualized.

Complicating this set of circumstances even further is how the Italian "Catholic Church has a strong influence on [...] lifestyle and lawmakers, especially when it comes to the issue of ethics. The politics of Italy seem to be intertwined with the teachings preached by the Roman Catholic Church and the policies of the Vatican" (Lorenzetti \& Viggiani, 2015, p. 121). Indeed, the Church has always intervened through friendly Italian politicians and the media (Cafasso, 2014) every time LGBT rights were taken into consideration at the legislative level. Through this framework, in addition to LGBT citizenship rights and their visible presence in the public space, we will highlight the importance of women's daily practices of resistance and negotiation with institutions (schools, workplaces, local governments, etc.). We are also interested in how our interviewees accept or reject heteronormative assimilation, and the coping mechanisms they use.

\section{Research design}

This article stems from our fieldwork (2015-2017) in the context of a fiveyear-long, ERC-funded ${ }^{1}$ research project called INTIMATE-Citizenship, Care and Choice: The Micropolitics of Intimacy in Southern Europe. This research aims at rethinking citizenship, care, and choice through the findings of a comparative and qualitative study that explored LGBT experiences of partnering (namely, lesbian coupledom and polyamory), parenting (mothers and fathers through assisted reproduction), and friendship (transgender networks of care and living with friends in adult life) in three Southern European countries: Italy, Portugal, and Spain.

In order to contextualize how intimacy was experienced in each country, we referred to data from secondary sources to complete a country-specific legal and social policy analysis. Overall, we gathered 90 in-depth biographical interpretive narrative interviews (Wengraf, 2001) with LGBTQ participants, and 60 semi-structured interviews with experts in the fields of law, politics, activism, academia, and health. For this article, we will take into consideration the Italian sample, focusing on two interviews with experts 
(Miryam Camilleri, lawyer and activist; Antonia Ciavarella, librarian and activist) and 16 interviews conducted in Rome with lesbian, bisexual, and pansexual, cis, and transgender women, focusing on issues such as intimate relationships, motherhood through assisted conception, and friendship.

\section{Recruitment strategies}

The sample was selected using a snowball method as well as a call for interviewees on websites of LGBTQ associations, virtual groups, institutions, and social networks. Inclusion criteria for the three studies required participants to: (1) be between the ages of 25 and 45 (even though we considered participants up to 48); (2) live in the capital city; and (3) identify themselves as either lesbian, bisexual, queer, or trans women.

\section{Participants}

This research comprises the narratives shared by 16 able-bodied, economically precarious (with low economic capital and high levels of cultural and social capital), white Italian LBTQ women living in Rome (see Table 1). We focus on the biographical data provided by the following interviewees.

\section{Data analysis}

Concerning in-depth interviews, empirical research was carried out using the biographical narrative interpretive method (BNIM) (Wengraf, 2001), which encourages the interviewee to speak as freely as possible in response to a single initial question, which focused on the narratives about intimacy along their life course. After the response to the initial question (which varied in length between 13 and 116 minutes), the interviewer seeks further details about events and experiences that had been mentioned in the first part of the interview. Interviews lasted from two to five hours, with an average length of almost three hours.

All interviews were audio-recorded and transcribed verbatim. To protect participants' privacy, all interviews have been anonymized. Afterwards, they were analyzed using NVivo software, with nodes organized around 20 macro-themes chosen by the research team, and they were linked to sociological literature on intimate citizenship, care, choice, parenting, partnering, and friendship.

\section{Intimate citizenship within a Mediterranean welfare regime}

Italy is a Southern European country enclosed in the Mediterranean welfare regime (Ferrera, 2008), where well-being has historically been conceived as 


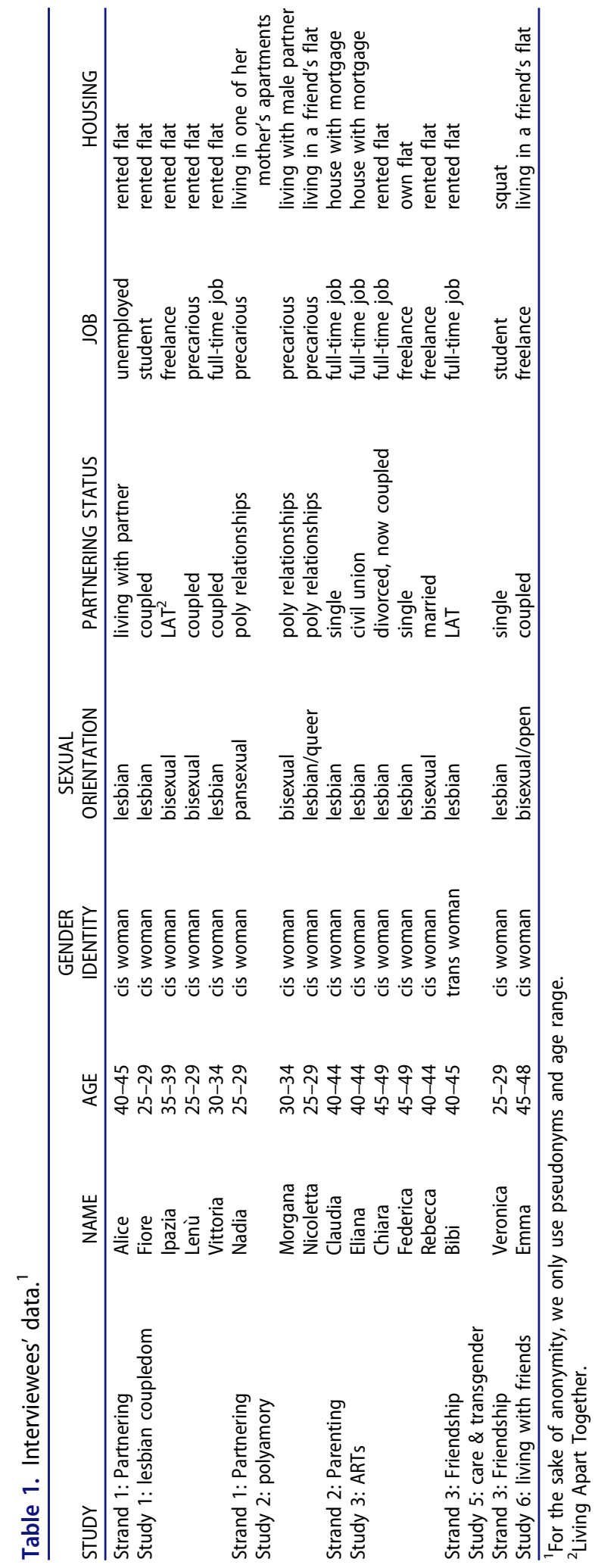


a private responsibility in line with "implicit" familialism (Leitner, 2003). This means that the transfer of resources and services are based on solidarity supported by family and kinship (Poggio, 2008), with social policies structured according to these same premises (Naldini \& Jurado, 2013). Given the centrality of family ties, heterosexual marriage still retains much of its institutional strength based on a familialist approach.

Three economic and political decisions exacerbated this familialist welfare regime: in the 1990s, Italy underwent a series of socio-economic reforms in order to enter the European Monetary Union (Ferrera, 2008); the 2001 Italian Constitutional reform of local authorities accelerated the transference of responsibility from central government to local administrations, and the outsourcing of services, with the consequent undermining of the universalist, public nature of the welfare state (Brenner \& Theodore, 2002); finally, in response to the financial crisis and austerity of the last 10 years, Italian politics paved the way to typical neoliberal reforms, worsening the dismantling process of the welfare state (Di Feliciantonio, 2016); access to services, education, healthcare and employment thus became arenas of private responsibility (Bertone \& Gusmano, 2013). This economic and social turn condenses the neoliberal background to the legal situation concerning intimate citizenship over the last 40 years: LGBT policies shifted from a focus on social rights, as a means of fighting against inequalities, to merely defending civil and relational rights (Cooper, 2006; Richardson \& Monro, 2012) in a form that does not question unequal social structures (nor mainstream mononormative ${ }^{2}$ assumptions) (Bertone \& Gusmano, 2013; Gusmano, 2017). Finally, homophobic political discourse remains hegemonic under the repressive tolerance (Mudu, 2002) of Catholic institutions and political parties (Di Feliciantonio, 2015), as demonstrated by the approval of Act 76/2016 on same-sex civil unions, after a heated debate that cancelled the provision of stepchild adoption (Lasio \& Serri, 2017).

Act 76/2016 established civil unions for same-sex couples and de facto cohabitation both for different-sex and same-sex couples. Stepchild adoption was set out in the original bill, but this was eliminated after a legislative debate in the Senate. Therefore, the Italian family law currently only allows marriage for heterosexual couples, civil union (merely described as "specific social formations") only for homosexual couples, and de facto cohabitation for both homosexual and heterosexual couples. Hence, the hierarchy between heterosexuality and sexual dissidence is preserved. Following Francesco Bilotta (2011), we presume that the recognition of a full-fledged same-sex marriage, undifferentiated from the heterosexual one, could have implied a change in the representation of the so-called "traditional family" (heterosexual and patriarchal) in the collective consciousness. 
The new law on same-sex civil unions is similar to the institution of marriage with regard to property agreement, inheritance, reciprocal assistance, and immigration. There are, however, substantive technical differences between civil union and marriage in the way they are formed; in the language employed (civil unions are "established," while marriage is "celebrated"; "parts" instead of "spouses"; "common life" instead of "family life"); in the way sex is referred to (no requirement for consummation and no loyalty obligation in civil union); and in the denial of parenting rights.

Therefore, Act 76/2017 failed to radicalize the legal system. Civil unions do not protect offspring and purposely do not impose fidelity in order to reproduce the stereotypical image of homosexual people as unfit to pursuit long-lasting projects. De facto cohabitation is just for couples, showing inadequacy to protect other intimate ties besides romantic love. In the next sections, we will concentrate on the Italian legal framework to show how it forges intimate citizenship.

\section{Lesbophobia through invisibilization: How law and stigma shape lesbian everyday life}

In this section, we will illustrate how lesbian, bisexual, and pansexual women are affected directly and indirectly by the law and by their broader sociocultural context.

As the ILGA-Europe rating $(2018 \mathrm{a}, 2018 \mathrm{~b})$ clearly shows, Italy rates rather poorly compared to other European countries with regard to LGBT rights: the Rainbow Europe Country Ranking (https://www.rainbow-europe. org/country-ranking) ranks Italy as 41 among 49 countries in the category Equality and Non-discrimination; 26 in the category Family; 24 in the category Legal Gender Recognition and Bodily Integrity; in first place, together with 33 other countries, in the category Civil Society Space; in ninth place, with 12 other countries, in the category Asylum. Finally, regarding the category Hate Crime and Hate Speech, Italy is in last place, together with 14 other countries that do not have any legislation on this matter. Indeed, the most recent attempt to promote a law against homophobia and transphobia was bill $245 / 2013$, which proposed to add sexual orientation and gender identity as motivations to two already existing laws against hate crimes based on racial, ethnic, and religious motives. This bill was approved by the Chamber of Deputies, but never got to the Senate. Therefore, naming homosexuality as a ground for legal protection against discrimination continues to be denied by law, with the exception of discrimination at work, an area where Italy has, albeit partially, complied with the European Directive 2000/78/EC, establishing a general framework for equal treatment in employment (legislative decree 216/2003). 
Given the austerity context, the most deep-felt issue concerning working conditions is not discrimination, but the fact of (not) having a job. In our sample of 16 women, only five have a permanent job, seven have precarious jobs, one is unemployed, and two are still studying while receiving financial support from their parents. For example, Nadia lives in a flat owned by her mother. She does different precarious jobs, and her retired father sometimes still helps her with extra expenses (gym, car insurance, etc.). Therefore, networks are deemed fundamental in order to manage capitalistic times, as affirmed by Veronica, a student who lives in a squat:

The lifetimes that capitalism imposes on you are ugly; that is, some people have to do two or three jobs to survive. We reject this logic, and we do it in different ways: firstly, through a collaborative lifestyle. [Veronica]

Parenting is the situation in which it is more evident how indirect work discrimination affects lesbians' lives. While self-employed women in our study can afford to manage their attempts to get pregnant (Chiara and Federica) without worry, those whose work is precarious need to stop working in order to go through assisted reproductive technologies (herein ARTs). Rebecca and her partner decide to go abroad between one job and the other, something that is only possible when one has a temporary job:

We made four attempts in four consecutive months because, at the time, we both worked [and] we stopped [...] because, if a project started, we would have been blocked for months and months. [Rebecca]

Parental leaves and breastfeeding are not granted in precarious contracts, so couples need to decide who can continue working. Rebecca decides to stop working since her partner's professional level is higher. On the other hand, having a permanent job allows women to appeal to the law on parental leave and breastfeeding, a useful provision, especially for single mothers; Claudia, employed in a public hospital, could take a vertical part-time ${ }^{3}$ job once a week for one year, thanks to the law on parental leave for single women.

The experiences of our interviewees show how, even when lesbophobia and stigma do not occur in the form of actual hate crimes, they produce consequences at the sociocultural level. Indeed, in our sample, we did not find any hate crime related to the fact of being lesbian, but many interviewees reported on how they had to manage their stigmatized and invisibilized sexual identity:

In the 70 s in Italy [... ] it was already an achievement to accept homosexuality; for me, being gay and Catholic was devastating. [Claudia]

[During high school] we did not know any person who defined themselves [as] a lesbian. [Fiore] 
After starting to define herself as bisexual, Ipazia faces what being part of an oppressed minority could mean: her first partner does not want them to be publicly visible because of fear of discrimination due to homo- and lesbophobic events spread by the media. Indeed, perceived lesbophobia and biphobia can produce as much of an impact as their direct experience (Trappolin \& Motterle, 2012). In order to counteract this lesbophobic underlay, lesbian women opt for visibility as a strategy of resistance:

I didn't hold myself back: on the contrary, I brought Ambra on my side. I said "Why should we limit ourselves? They are $[\ldots]$ the ones who should change their attitude." [Ipazia]

I've been living like that [publicly visible as a lesbian] for 10 years, since when I came out. [...] Paradoxically, I never got insulted or discriminated against [....] Personally, I think that's the only solution, the only way to... well, to change something, maybe. [Vittoria]

Bibi's story tells us about the intersection of stigma and discrimination since, she says, she does not always know whether she is being stigmatized for her lesbianism or for her gender identity:

I never know whether the prejudice is connected to my [...] lesbian relationship or if there is the aggravating factor of [being] trans. [...] And I feel that [aggravating factor]. [Bibi]

According to the mothers interviewed, they have not been discriminated against because they are lesbians, but they have been feeling the negative impact of heteronormativity, since none of them thought that it was possible to be a lesbian and a mother at the same time. Literature defines this common feature as "minority stress." 4 Many women in their forties to fifties affirm that they always thought of lesbian motherhood as impossible, due to Catholicism or the heteronormative tradition:

I thought that the "pure" lesbian could not have children; I remember at school [...]

I used to think: "no, I am homosexual, I will not marry, I will not have children, I

will go my own way, I will do well.” [Chiara]

But I also had this whole period when I was discovering myself that I really wondered whether it was right or not that a homosexual person had the right to give birth to children... I repeat, I come from a very traditional family. [Federica]

In contrast, Lenù, who is still in her thirties, talks about motherhood as a taken-for-granted desire for her and her partner. However, she already predicts negative reactions from her lesbophobic mother, in the hypothetical event that she would become a parent:

Family approval is really the first one, the most primordial, most archaic one.... And maybe it's also because of this [mother's disapproval] that I see the idea of having a child as something so far away.... I mean, these things take away from you the perception that this could actually happen. [Lenù] 
Her words show how the decision to become a mother reinforces lesboand biphobic stigmatization, even for women of younger generations, who may not have internalized the lesbophobic stigma as strongly as older generations. ${ }^{5}$ Once women decide to become parents, they have to justify their choice to relatives and/or friends who are worried that children of samesex parents are doomed to suffer homophobia. Tired of these fruitless debates, during a conversation with some friends of hers, Rebecca comes up with the metaphor of a Picasso painting:

What do you do with a Picasso with an ugly frame: do you throw away the Picasso? No, you get rid of the frame.... That conversation seemed weird to me: it was as if we were in a dinner between Black people, and a Black person would say to another [Black person]: "no [you should not have children], otherwise they call him 'Black' at school.” [Rebecca]

Indeed, lesbian and bisexual mothers are more worried about the homophobia their children might face at school (Bos et al., 2004). For this reason, they enroll their children in multicultural schools in order to expose them to diversity (Gartrell, Bos, \& Goldberg, 2011). For example, Chiara and her ex-wife's two boys are attending a Steiner elementary school:

Children go to a school that is $[\ldots]$ multi-ethnic $[\ldots]$ there is an incredible variety of... different types of families. And they were very, very well welcomed, as well. [Chiara]

Referring to these parental practices, Bosisio and Ronfani talk about "a sort of anticipatory socialization" (2015, p. 75), which would help children to grow up learning diversity, tolerance, and respect for differences, in order to improve their well-being. Lesbian mothers are especially worried about how to raise a male child in a patriarchal and misogynistic society:

$\mathrm{He}$ is a little man who is raised by two women, and who... will grow up, he will cope with the female gender. And I bet on this kid... hoping that there is the possibility of having budding of different males. [Rebecca]

This strategy is employed by same-sex parents in order to protect their children from heteronormative environments where, as testified by Federica, the common insult is "faggot." Parents try to contribute to their children's psychological well-being through time shared within the LGB parents' association in order for their children to get to know more families like theirs.

\section{No country for lesbians: Partnership and parenting despite the law}

Three laws affect lesbian intimate lives in Italy: Act 76/2016 on same-sex civil unions, Act 40/2003 on medical assisted reproduction, and Act 184/ 1983 on adoption. 


\section{Act 76/2016, "Regulations on Civil Unions between Same-Sex Persons and Discipline of Cohabitation"}

The very first law on the recognition of same-sex couples entered into force after 30 years of failed proposals. Since we conducted the majority of our interviews before the approval of the law or just after it, this was a very hot topic, and it comprised a deep analysis of what it means not to be recognized as a mother of one's own child. Even though we will focus on parenting in the following sections, here we explore what it means not to be able to appeal for the provision on stepchild adoption that was in the bill.

Alice talks about her relationship as "a full-fledged marriage": they have been living together for years, and supporting each other emotionally and materially. As members of the Waldensian Evangelical Church, ${ }^{6}$ they could have had a blessing ritual as a couple, but they were not interested in a merely symbolic recognition:

When our union will be legally recognized, then we will do as all the other

Waldensian couples do: they get married both in church and city hall. [Alice]

Similarly, Vittoria underlines the material importance of marriage for the rights of homosexual people who want to take care of each other, with rights, duties, and full citizenship.

Lenù was also interviewed before the approval of the civil union law. She and her partner Noe, a lesbian cohabiting couple in their thirties, were thinking about moving abroad, not only to find a better job, but also to have children legally. In her narrative, it clearly emerges that, for a young lesbian couple sharing the desire to "start a family," the economic issue (which affects the majority of their generation) intersects with the absence of any kind of law granting same-sex partnering and parenting. On the other side, her case is an example of resilience when confronted with the total lack of legal support: here, resilience has to do with the idea that even a couple needs a community, a social network, in order to take care of a child:

At the same time, I don't think it's totally impossible to raise a child here. I mean, surely there's a network of rainbow families. [Lenù]

When same-sex partnering rights were finally recognized, a provision on stepchild adoption was eliminated from the bill that would become Act 76/ 2016, due to strong opposition by right-wing, conservative, and Catholic politicians. This represented a serious setback for lesbian and gay parents, who had been waiting for that provision in order to be legally recognized even though they are not the biological parent. As a result, their situation continues to be precarious and dependent on case-by-case court decisions: 
They came together: the sweetness of Valentino and the harshness of the law.... Explain to a 5-year-old boy that his is not a family.... Valentino would have been born anyhow. Whether you recognize it or not, nothing changes to the State. To us, it changes the world. [Rebecca]

Interestingly enough, the provision on stepchild adoption was eliminated because Catholic and conservative political forces interpreted it as a way to encourage surrogacy practices among gay men. The issue of surrogacy was strategically used by the mainstream media as well. As a result, lesbian mothers were invisibilized both in the public debate and in the legislative process.

Not being legally recognized in their path of same-sex parenting and partnering also affects interviewees' social acceptance: homoparenting is "an exceptional detector of the shortcomings and contradictions of our law system" (Théry, 1993, p. 30). Italian legislation shows that parents are supported in their reproductive rights only when they are a monogamous heterosexual couple. This lack of full institutional recognition for same-sex families reinforces their members' vulnerability (Bosisio \& Ronfani, 2015):

If you introduce marriage in a country, it doesn't mean that homophobia, discrimination and so on will automatically disappear, but it is a huge message. Moreover, it would give huge courage to all those people who have great difficulties in living [their lives as homosexuals]. Besides, it would solve concrete and material problems. [Miryam Camilleri]

Therefore, interviewees try to protect their family, their partner, and their children through other notarial tools that could be used if the legally recognized mother is able to make decisions (i.e., due to accident, illness, or death). An example is the "parenting project document," a notarial will signed by Eliana and her partner. Briefly, it is a diary that demonstrates a permanent parenting project (showing receipts, shared bank accounts, mortgage, online school payments, etc.), the desire to take responsibility as a couple and as parents, and the will to also identify the co-mother as a holder of parenting responsibility (Bosisio \& Ronfani, 2015).

\section{Act 40/2004, "Norms on the Matter of Medically Assisted Procreation"}

The Italian law on assisted reproductive techniques (ARTs) disregards lesbian motherhood. ARTs are permitted only for married or cohabiting different-sex couples with documented infertility. This means that single women and same-sex couples have to go abroad (and pay considerable amounts of money) to have children using these techniques ${ }^{7}$. Some interviewees acknowledged that assisted reproduction is a political position against lesbian intimate life: 
[Insemination] is illegal only because we are women: in Italy, the homosexual couple is not recognized. [Chiara]

So, for (single or coupled) lesbian women residing in Italy, it is possible to have children by self-insemination with a known sperm donor, or by resorting to ARTs abroad, especially in countries where this is legal for lesbian couples and single women, such as Belgium, Denmark, Finland, Spain, Great Britain, and Greece. The biological mother can then have the child legally acknowledged as her biological son/daughter, while the co-mother is not legally recognized as a parent, with all the consequences this implies:

That pediatrician told her: "I am not authorized to give you any information," when the child was feeling sick [...]; other people had negative experiences: they brought them to the emergency room, they said: "you are not the mother." [Eliana]

Because, you know, things are easier for me, I'm the biological mother.... I understand Debora when she says: "I feel... that is my son, I know that he is my son, but the State does not recognize me and gives me continuous input so that I do not feel I am a parent." [Rebecca]

Harding (2011) writes about "illegitimate parents," meaning those parents who do not have any legal relationship to the children they are taking care of. It seems clear how the politics of biology consist of discourses, fuelled by biological determinism and heteronormativity, granting legal and cultural priority to biological kinship ties (Lenke, 2009).

These women do not tend to act as victims, notwithstanding episodes of misrecognition in the public administration. Federica talks about her doctor's judgemental reaction when she went there to ask for referrals. Rebecca recalls when she went with her partner to the Registry Office and the employee insisted on asking for a father's signature. They are able to find helpful resources that do not comply with the narrowness of the law, thanks to the help they get from health professionals. Rebecca tells about how her gynecologist, disappointed by the law ban for single and lesbian aspiring mothers, provided her with infertility prescriptions that in Italy are given only to infertile heterosexual couples:

"No, you pay taxes and everything, you are a citizen like any other; you and Debora are a couple who have fertility problems, objectively." [Rebecca]

Recognizing the right of non-heterosexual women to be mothers is not just a matter of citizenship, but of material conditions as well. Assisted reproduction requires medicine, travel, check-ups, and a forward-looking plan concerning the maximum number of tries. Therefore, banning lesbian and single women from access to Act 40/2003 is a class issue:

Even from an economic point of view, here I say: this is something for rich people, and I find it... an absurd discrimination.... Thus, you are forced to go abroad, and 
I made them send me medicines because they cost less in Spain. But it was $€ 1500$ every month, just for medicines. [Federica]

Besides buying expensive medicines abroad, other strategies included working in the health sector, and therefore having cheaper access to medicines and check-ups, or being referred to the lesbian and gay parents' association to get advice concerning the best procedures.

\section{Act 184/1983, "The Child's Right to a Family"}

With regard to full adoption, according to Act 184/1983 (modified in 2001), only couples who have been married for at least three years (or, if not, who have been cohabiting for at least three years before they marry) can access it. Some courts ruled that full adoption is legitimate for samesex couples. The Court of Appeal of Milan, in its decision of 16 October 2015, legitimized the transcription of a Spanish court decision on full adoption for the social mother. In 2016, with decision no. 19599, the Supreme Court accepted the transcription of the birth certificate of the child of a lesbian couple (an Italian and a Spanish woman) who had resorted to reciprocal IVF. This law sets out the so-called "adoption in particular cases" (art. 44), according to which a person who does not meet the requirements for full adoption can nonetheless adopt a child, as long as they already have an intimate bond whose rupture would damage the minor. Resorting to art. 44 is the only way for social parents to access stepchild adoption. Moreover, in the last few years-given the contradictions between the lack of legislation and the growing claims from LGBT individuals, couples, and parents ${ }^{8}$ - Italian courts have been making decisions based on the national Constitution and European legislation.

The Juvenile Court of Rome resorted to art. 44 in its decision of 30 July 2014, the first one in Italian history where the adoption of a stepchild by a same-sex couple was approved. Two Italian women had a child with ART abroad and the social mother asked to adopt the girl. In accordance with art. 44 (d) of Act 184/1983, pre-adoptive placement was not possible since the child was not legally adoptable (she already had a mother), and the court ruled that the social mother could adopt the child as a single woman who had intimate bonds with the girl. It also ruled that the child could adopt the surnames of both mothers. Right between the approval and the entry into force of Act 76/2016, the Supreme Court, with decision no. 12962 of 26 May 2016, ${ }^{9}$ confirmed the earlier decision and the legitimacy of stepchild adoption. With this breakthrough decision, the Supreme Court ruled that the impossibility of pre-adoptive placement set out in art. 44 (d) should be considered not only a practical impossibility, but also a juridical one. 
Interestingly enough, the limitation for different-sex married couples is not imposed in the case of temporary fostering, so that homosexual people can temporarily foster (not adopt) children (Bilotta, 2011). Even so, the law (art. 2) provides a hierarchy as regards the choice of foster parents: the first choice should be a family, preferably with children; the second choice could be a single woman or man; the third and the fourth (to be avoided as much as possible) could be foster communities, and public or private foster institutes. In 2013, three different courts (Palermo, Parma, and Bologna) ruled that a same-sex couple could foster a child, provided that social services ascertain that the couple is stable and that they can attend to the child's best interests. These decisions were based on the fact that the law provides that a single person can foster a child. It follows that two persons together can also do it (independently from their relationship) (Conti, 2013; Ruggeri, 2013). With regard to married trans* parents who obtained the rectification of sex attribution, before Act 76/2016 came into force, they had to face the issue of their child custody immediately after rectification, since that automatically led to the annulment of marriage, regardless of the couple's will (Act 164/1982). ${ }^{10}$ Act $76 / 2016$ sets out the automatic transformation of marriage into civil union, resolving this controversial issue.

\section{Outside the boxes: Co-housing and friendship}

The Italian law does not foresee any formal recognition of the importance of friendship nor of any kind of relationship beyond the mononormative family structure. The fact is that being recognized in their intimate life choices is exacerbated for minority groups (Tronto, 1987), such as LGBT people, who rely more on networks than on kinship (Weeks, Heaphy, \& Donovan, 2001; Weston, 1991):

The subjects who are not included in the constitutional framework are freer to reinvent themselves [...] because they need a fabric of understanding and experiences that necessarily leads to openness. [Antonia Ciavarella]

Lesbian women find alternative arrangements to those recognized by law. They try to get out of the boxes of normativity. In this dimension, one of the most material decisions concerns living arrangements: Emma and Nicoletta opt for an extended cohabitation with chosen friends, and consider it a political project whose aim is to share both positive and tough moments:

It is a political project, it is a family project understood as a nucleus that comes together to face beautiful things and bad things. [Nicoletta]

Friendship is commonly considered as a voluntary and not ascribed social relationship that receives far less formal recognition than biological 
ties (Friedman, 1993). Conversely, friends are indispensable not only for survival, but for a positive existence, as expressed by Emma, a workingclass sculptor who can count on her friends' help during tough moments, such as unemployment or need for housing:

They are a network of positive existence, rather than of survival [:] I think the salvation of my generation, to put it in very edged terms, is networking. Thus, it also becomes a salvation, a political choice... I do not believe in narrow groups. [Emma]

Concerning housing conditions, interviewees confirm a general tendency of not being able to own a house anymore, as shown in Table 1.

On the one hand, interviewed mothers are concerned with their housing before deciding to go through ARTs. In fact, out of five mothers, three live in the house they own:

Already in 2009, I had this almost visceral desire to have a child [...] but first I thought that, in order to have a child, I needed to own a house. So Sandra and I decided to buy a house. [Eliana]

With Tiziana, before we broke up, we had started to attend groups of families, sorts of commune, that were co-housing... what comes back is always the fact of being together, to build, even with my friends, always these beautiful networks of solidarity. [Chiara]

On the other hand, many women are trying to think about alternatives to nuclear families: Morgana, aware of the impossibility of paying two rents, dreams of a polyhouse where she could live with both her girlfriend and boyfriend, with private intimate rooms and open common spaces. Similarly, some interviewees think about grassroots plans to overcome "metropolitan loneliness": Veronica is living in a squat where they are considering presenting to the local government a co-housing project to revitalize abandoned public spaces as a means to cope with social uncertainty and material conditions:

The lack of jobs; the prolongation of training time: in a metropolis with rents that even go up to $€ 500 / 600$, if you include utilities, there is still a very small margin to make a decent living.... This is a space in which social activities are carried out, and a certain way of life is safeguarded which, somehow, saves people from metropolitan loneliness. [Veronica]

Of course, Veronica is aware of the institutional backlash, and she knows that institutions sometimes try to delegate to grassroots associations the task of coping with welfare inefficacy:

However [the president of the town hall] proposed us absurd things, like "do activities for the elderly." [Veronica] 
There are no social policies in Italy that contemplate the possibility of citizens planning their future outside nuclear families. Trying to imagine a shared collective space beyond biological ties even needs new language. Nadia comes up with a neologism to refer to her friends, since in the culture there is a deep hierarchy between relatives and friends:

[Polyfamily]: a humane assistance, of listening, and also a practical one, where everyone puts at disposal what they know and how to do it... . More than anything, I realized that ... these friends, lovers, are becoming a family. [Nadia]

Friendship is a central choice in the personal path of many bisexual and lesbian women (Roseneil, 2007; Weston, 1991), challenging the idea of family as merely based on biological ties in order "to be able to think of the family not in terms of biology but in coalitions of affinity" (Lenke, 2009, p. 100):

There is an extended family, it really exists. You have to build it, eh, it does not come out of the blue. [Federica]

I was lucky enough to find a network of LGBT people [during adolescence], among other things in a provincial town in Southern Italy, and [...] to see very soon that I was not the weird one. [Veronica]

[Adele and I] made the decision that she would stand beside me in my desire for parenting, but she was not another mother.... For me she was [...] the fundamental element [:] not only a practical help, but also a moral and emotional support in this desire. [Claudia]

Many women focused their narratives on the help they received from friends during their life course. They were economically precarious, but they could rely on friends when they did not have a job or a house. As adolescents growing up in a Catholic or traditional context, LGBT friends were the litmus test of the availability of a life outside heteronormativity. As single mothers, they could count on close friends who helped them take care of their children.

\section{Between invisibilization and resistance: A conclusion}

The experiences of our interviewees reveal how strongly legal background, social stigma, and invisibilization influence their daily lives and their intimate projects. "Privatization is one way in which heteronormative processes operate" (Carabine \& Monro, 2004, p. 20); thus, one strategy of resistance consists of inhabiting that space through arrangements that are out of the boxes of normativity. The experiences of many lesbian and bisexual mothers are an example of the "margins of creativity and social invention" (de Cordova \& Sità, 2014, p. 401) that people produce and live in when they are not recognized by law. Daily-life strategies enacted by lesbian mothers (and other unrecognized groups) can help produce "unexpected spaces of 
possibility in already defined sets of rules" (de Cordova \& Sità, 2014, p. 401). This means the private space is always political and individual experiences contribute to building the collective milieu.

At the same time, these women show different counteractions: resorting to courts; actively and creatively interacting with local authorities; finding ways outside of the law to form families, kinship, and other intimate networks of reciprocal care. Their practices are influenced by material conditions that allow them (or not) to access ARTs, own a house, travel abroad, and so on. Therefore, with regard to narratives of choice, we should be aware that "choice' does not exist as a free floating abstraction but rather is often a mobilisation and manifestation of classed resources" (Taylor, 2009 , p. x). Hence, choice should be read at the intersection of legal frameworks, policies, economic capital, and social networks that impact how we cope with different systems of oppression, such as heteronormativity, lesbophobia, and invisibilization. The lack of recognition of their relationships impacts the level of vulnerability of lesbian, bisexual, and trans* women, especially during times of crisis (from medical emergencies to economic issues). Indeed, aiming at being recognized as a family is also a strategic means to be entitled to material benefits (de Cordova \& Sità, 2014).

The central place of the family and familialist demands of LGBT struggles sometimes tend to advocate for the homonormativization of rights. Nonetheless, it is worth considering that the intimate and political reconfiguration of homoparental families, and lesbian and bisexual single mothers, is not always and only an imitation of the "traditional" heterosexual family. For example, if, on the one hand, having children could lead lesbian women to reproduce the heteronormative form of family (as Antonia Ciavarella recalled in her interview), on the other hand it could imply an intimate and social reinterpretation of kinship practices. It is clear that the familialist rhetoric still permeates Italian political, legal, and public discourse against non-heterosexual intimate practices, as well as mainstream LGBT struggles advocating for assimilation into the hetero and mononormative family. This rhetoric contributes to erasing many forms of kinship and parenting (Bertone, 2015; Bosisio \& Ronfani, 2015), leaving aside other networks of reciprocal care, such as friendship, which constitute the safe haven of unrecognized intimate bonds.

\section{Notes}

1. INTIMATE is funded by the European Research Council under the European Union's Seventh Framework Programme (FP/2007-2013)/ERC Grant Agreement no. 338452.

2. The term mononormativity was coined by Pieper and Bauer (2005) to refer to the forms of power which help establish the monogamous couple bond as an idealized and normative model. 
3. This is part-time work where one works full-time only on some days of the week, month, or year. A synonym is "full-day part-time."

4. In everyday life, the experience of stigmatization is related to being part of a minority group. "Minority stress can be distinguished into several dimensions, such as actual negative experiences, expectations of rejection and discrimination, and internalized homophobia." (Bos, van Balen, van den Boom, \& Sandfort, 2004, p. 292). For references on homosexual parenting in the Italian context, please see Bosisio \& Ronfani (2015).

5. The most representative research on Italian gay and lesbian people (Barbagli \& Colombo, 2001) pointed out that the desire of motherhood is inversely proportional to age.

6. The Waldensian Church is an Italian branch of the Evangelical and Methodist Church, which explicitly supports and celebrates same-sex marriages.

7. With regard to same-sex couples involving trans* people who concluded the procedure for the so-called "rectification of sex attribution" (Act 164/1982) and want to have children, they will have to resort to assisted reproductive technologies. Indeed, the procedure of rectification necessarily requires destructive surgery of the internal and external reproductive organs and, as a consequence, sterilization (or at least sterilization, even without surgery), according to the vast majority of jurisprudence. In 2017, the Constitutional Court, with decision no. 180, confirmed that surgery is not mandatory, but it did not explicitly exclude the necessity of sterilization.

8. Out of 1391 LGBTQ families interviewed between 2016 and $2017,28.6 \%$ (16\% of whom are single) have at least one child; out of these $394,75 \%$ are women, $7 \%$ had children through auto-insemination, 41\% through ARTs (Centro Risorse LGBTI Famiglie Arcobaleno \& Rete Genitori Rainbow, 2017).

9. "Because the Italian judicial system is based on Civil Law, within the framework of late Roman law [... judicial decisions by the Supreme Court [...] do not constitute the base for judicial precedent for other future cases. [...] However, on a more practical level, the decisions of the Supreme Court usually provide a very robust reference point of constant jurisprudence" (Lorenzetti \& Viggiani, 2015, p. 120).

10. With its decision no.14329, of 6 June 2013, the Court of Cassation raised a question of constitutional legitimacy about such provision. The Constitutional Court, with decision 170/2004, ruled that art. 2 and 4 of Act 164/1982 ("Rules Concerning the Rectification of Sex-Attribution") are unconstitutional, inasmuch as they do not give the couple the freedom to keep on having a legal partnership. As Italian law does not provide any other legal partnership besides heterosexual marriage, the Court in such decision gave the legislator the task of providing legal alternatives to guarantee samesex couples' rights.

\section{Notes on contributors}

Beatrice Gusmano is a feminist sociologist interested in LGBTQ relationships; lesbian motherhood through ARTs; LGB friendship and cohabitation; LGBT local and national public policies; and bullying and gender education. She is currently working on the project "DomEQUAL: A Global Approach to Paid Domestic Work and Global Inequalities" based at $\mathrm{Ca}^{\prime}$ Foscari University in Venice (Italy).

Tatiana Motterle worked on the ERC-funded project "INTIMATE-Citizenship, Care and Choice: The Micropolitics of Intimacy in Southern Europe" (2014-2019). She also took part 
in national and international research projects about homophobia in Europe, Female Genital Modifications, and social care and work-care balance. She is a transfeminist and anti-speciesist activist.

\section{ORCID}

Beatrice Gusmano (D) http://orcid.org/0000-0003-1645-1044

Tatiana Motterle (D) http://orcid.org/0000-0001-8706-4493

\section{References}

Barbagli, M., \& Colombo, A. (2001). Modern Homosexuals: Gays and lesbians in Italy. Bologna, Italy: Il Mulino.

Bertone, Chiara (2015). The discreet charm of homoparental families: Dilemmas and responsibilities in research. Cambio 5(9), 37-45.

Bertone, Chiara \& Gusmano, Beatrice (2013). Queerying the public administration in Italy: Local challenges to a national standstill. In M. Addison \& Y. Taylor (Eds.), Queer presences and absences: Time, future and history (pp. 260-278). London, England: Palgrave Macmillan.

Bilotta, Francesco (2011). Homoparenting, adoption, and foster care. In A. Schuster (Ed.), Homoparenting: Filiation, sexual orientation, and law (pp. 163-230). Milano, Italy: Mimesis.

Bos, Henny, van Balen, Frank, van den Boom, Dymphna, \& Sandfort, Theo (2004). Minority stress, experience of parenthood and child adjustment in lesbian families. Journal of Reproductive and Infant Psychology 22(4), 291-304.

Bosisio, Roberta \& Ronfani, Paola (2015). Homoparental families: Responsibilities, rules, and rights. Roma, Italy: Carocci.

Brenner, Neil \& Theodore, Nik (2002). Building "Euro-regions": Locational politics and the political geography of neoliberalism in post-unification Germany. European Urban and Regional Studies 7(4), 317-343.

Cafasso, Samuele (2014). Children of the rainbow: Lesbian mothers, gay fathers, denied rights in Italy. Roma, Italy: Donzelli.

Carabine, Jean, \& Monro, Surya (2004). Lesbian and gay politics and participation in New Labour's Britain. Social Politics 11(2), 312-327.

Centro Risorse LGBTI, Famiglie Arcobaleno, \& Rete Genitori Rainbow (2017). LGBTQI families. Retrieved 25 July, 2018. http://www.risorselgbti.eu/contiamoci-famiglie-lgbtqi/

Conti, Roberto (2013). On the fostering of a child to a same-sex couple: First notes on the decisions of Parma Tutelary Judge (July 3, 2013) and Bologna Juvenile Court (October 31, 2013). Matter: Justice. Retrieved 9 March, 2018. http://www.questionegiustizia.it/doc/ Su_affidamento_di_un_minore_a_una_coppia_dello_stesso_sesso.pdf

Cooper, Davina (1995). Power in struggle: Feminism, sexuality and the state. Buckingham, England: Open University Press.

Cooper, Davina (2004). Challenging diversity: Rethinking equality and the value of difference. Cambridge, England: Cambridge University Press.

Cooper, Davina (2006). Active citizenship and the governmentality of local lesbian and gay politics. Political Geography 25(8), 921-943. 
de Cordova, Federica \& Sità, Chiara (2014). In sickness and in health, in poverty and in wealth. Homoparental families and rights in Italy from a psychosocial perspective. In C. Casonato C. \& A. Schuster (Eds.), Rights on the move: Rainbow families in Europe: Proceedings of the conference: Trento, 16-17 October 2014 (pp. 397-407). Trento, Italy: Università degli Studi di Trento, Facoltà di Giurisprudenza.

Di Feliciantonio, Cesare (2015). The sexual politics of neoliberalism and austerity in an "exceptional" country: Italy. ACME: An International E-Journal for Critical Geographies 14(4), 1008-1031.

Di Feliciantonio, Cesare (2016). Subjectification in times of indebtedness and neoliberal/ austerity urbanism. Antipode 48(5), 1206-1227.

Ferrera, Maurizio (2008). Welfare state reform in Southern Europe: Fighting poverty and social exclusion in Italy, Spain, Portugal and Greece. London, England: Routledge.

Friedman, Marilyn (1993). What are friends for? Feminist perspectives on personal relationships and moral theory. Ithaca, NY: Cornell University.

Gartrell, Nanette, Bos, Henny, \& Goldberg, Naomi (2011). Adolescents of the U.S. National Longitudinal Lesbian Family Study: Sexual orientation, sexual behavior, and sexual risk exposure. Archives of Sexual Behavior 40(6), 1199-209.

Gusmano, Beatrice (2017). Uncomfortable bargains? Networking between local authorities and LGBT associations in the context of neoliberalism. In I. Crowhurst, A. King, \& A.C. Santos (Eds.), Sexualities research: Critical interjections, diverse methodologies and practical applications (pp. 153-166). London, England: Routledge.

Harding, Rosie (2011). Regulating sexuality: Legal consciousness in lesbian and gay lives. London, England: Routledge.

ILGA-Europe (2018a). Rainbow Europe Index: May 2018. Retrieved 29 September, 2018. https://www.ilga-europe.org/sites/default/files/Attachments/index_2018_small.pdf

ILGA-Europe (2018b). Rainbow Europe Map: May 2018. Retrieved 29 September, 2018. https://www.ilga-europe.org/sites/default/files/Attachments/rainbow_europe_map_2018_ small.pdf

Lasio, Diego \& Serri, Francesco (2017). The Italian public debate on same-sex civil unions and gay and lesbian parenting. Sexualities. doi: 10.1177/1363460717713386

Leitner, Sigrid (2003). Varieties of familialism: The caring function of the family in comparative perspective. European Societies 5(4), 353-375.

Lenke, Karin (2009). Blood, water, and the politics of biology. In E. Oleksy (Ed.), Intimate citizenship: Private decisions and public dialogues (pp. 100-117). New York, NY: Routledge.

Lorenzetti, Anna \& Viggiani, Giacomo (2015). Italy. In Maria Federica Moscati (Ed.), Same-sex couples and the Mediation in the EU (pp. 115-148). London, England: Wildy, Simmonds \& Hill.

Mudu, Pierpaolo (2002). Repressive tolerance: The gay movement and the Vatican in Rome. GeoJournal 58(2-3), 189-196.

Naldini, Manuela \& Jurado, Teresa (2013). Family and welfare state reorientation in Spain and inertia in Italy from a European perspective. Population Review 52(1), 43-61.

Phelan, Shane (2001). Sexual strangers: Gays, lesbians, and dilemmas of citizenship. Philadelphia, PA: Temple University Press.

Pieper, M. \& Bauer, R. (2005). Polyamory und mono-normativität. In L. Méritt, T. Bührmann, \& N. Schefzig (Eds.), More than one love: Polyamoros relationships (pp. 59-69). Berlin, Germany: Orlanda.

Plummer, Ken (2003). Intimate citizenship: Private decisions and public dialogues. Seattle, WA: University of Washington Press. 
Poggio, Teresio (2008). The housing pillar of the Mediterranean welfare regime: Family, state and market in the social production of home ownership in Italy. Home Ownership and Globalisation Conference: Building on Home Ownership: Housing Policies and Social Strategies - OTB Research Institute for Housing, Urban and Mobility Studies, ENHR Working Group, Delft University of Technology, the Netherlands, 13-14th November.

Reynolds, Paul (2010). Disentangling privacy and intimacy: Intimate citizenship, private boundaries and public transgressions. Human Affairs 20, 33-42.

Richardson, Diane \& Monro, Surya (2012). Sexuality, equality and diversity. New York, NY: Palgrave Macmillan.

Roseneil, Sasha (2007). Queer individualization: The transformation of personal life in the early 21st century. NORA: Nordic Journal of Feminist and Gender Research 15(2), 84-99.

Ruggeri, Antonio (2013). Notes about fostering of minors to homosexual couples. Consulta online. Retrieved 23 February, 2019. http://www.giurcost.org/studi/Ruggeri32.pdf

Taylor, Yvette (2009). Lesbian and gay parenting: Securing social and educational capital. Basingstoke, England: Palgrave Macmillan.

Théry, Irène (1993). Marriage: Justice and private life. Paris, France: Jacob.

Trappolin, Luca \& Motterle, Tatiana (2012). One step beyond: Researching homophobia in Italian society. In L. Trappolin, A. Gasparini, \& R. Wintemute (Eds.), Confronting homophobia in Europe: Social and legal perspectives (pp. 21-50). Oxford, England: Hart Publishing.

Tronto, Joan (1987). Beyond gender difference to a theory of care. Signs 12(4), 644-663.

Weeks, J., Heaphy, B., \& Donovan, C. (2001). Same sex intimacies: Families of choice and other life experiments. London, England: Routledge.

Wengraf, Tom (2001). Qualitative research interviewing: Biographic narrative and semistructured method. London, England: Sage Publications.

Weston, K. (1991). Families we choose: Lesbians, gays, kinship. New York, NY: Columbia University Press. 